\title{
НАЧАЛЬНИКИ ВОЕННЫХ УЧЕБНЫХ ЗАВЕДЕНИЙ, ДИСЛОЦИРОВАВШИХСЯ В РЯЗАНСКОЙ ОБЛАСТИ В ГОДЫ ВЕЛИКОЙ ОТЕЧЕСТВЕННОЙ ВОЙНЫ
}

\section{HEADS OF MILITARY EDUCATIONAL INSTITUTIONS DISPLACED IN THE RYAZAN REGION IN THE YEARS OF THE GREAT PATRIOTIC WAR}

\section{G. Larin}

Summary: The scope of this article concentrates on those army officers and generals who were in charge of military educational institutions, located in Ryazan oblast during the Great Patriotic War. The article considers the issues of recruitment and appointment of the command staff. It presents the examined background information on the officers who ran military institutions during the World War II.

Keywords: military educational institution, military academy, military school, superintendent, Army General, officer, biography.

\author{
Ларин Геннадий Владимирович \\ Аспирант, Рязанский государственный \\ университет имени С.А. Есенина. \\ larin191975@yandex.ru
}

Аннотация: Статья посвящена генералам и офицерам, руководившим военными учебными заведениями, которые дислоцировались на территории Рязанской области в годы Великой Отечественной войны. Рассмотрены вопросы подбора и расстановки начальствующего состава. Изучены и представлены биографические данные начальников училищ и школ, руководивших ими в самый сложный период их функционирования.

Ключевые слова: военное учебное заведение, военное училище, военная школа, начальник, генерал, офицер, биография.

еначальников.

Для решения поставленных задач был определен круг необходимых архивных материалов и выстроена методология их исследования.

Основным источником документов, которые были изучены в ходе данной работы, является Центральный архив Министерства обороны РФ (далее ЦАМО). Хранящиеся в нем описи фондов того или иного военного училища, военной школы, воинской части, предваряются краткой исторической справкой. Информация, изложенная в справке, позволяет установить личности начальников военно-учебных заведений, а также командиров различных воинских частей и определить в хронологической последовательности нахождение их на должностях.

Следующий этап - используя штатно-должностную книгу того или иного военного заведения, устанавливаем год рождения и основные данные (воинское звание, образование, членство в ВКП(б), состав семьи и т.д.) об интересующих нас лицах. Основной информацией из вышеперечисленной является год рождения, в связи с тем, что построение офицерских картотек всех категорий в ЦАМО производится именно по данному параметру, а далее по алфавиту фамилий военнослужащих.

Используя полученные из кратких исторических 
справок и штатно-должностных книг краткие сведения, на следующем этапе работы с архивными материалами необходимо обратиться к специфическим документам из фондов архива ЦАМО. К ним относятся:

1. Личное дело офицера - самый основной источник информации с максимальным объемом различных документов. В нём имеются полные биографические данные, послужной список, награды и благодарности Верховного Главнокомандующего, автобиография, аттестационные материалы, служебные, партийные и боевые характеристики разных лет, наградные листы, документы об образовании.

2. Учётно-послужная карта офицера, в которой содержится биографическая информация в сокращённом виде, имеются данные о прохождении службы. Наибольший интерес в данном документе представляют сведения об образовании. Кроме того, зачастую встречается краткая характеристика военнослужащего, которая не отображена в личном деле.

3. Учётная карточка награждённого - в данном документе перечислены все награды офицера. В этом перечне наиболее ценной является информация об орденах и медалях с указанием их номеров, а также дат приказов или указов о награждении и наименовании органов, которые производили награждение.

На основании указанных, а также ряда других документов, были установлены личности всех начальников военных учебных заведений, дислоцировавшихся на территории Рязанской области в годы Великой Отечественной войны. Наиболее детально исследованы сведения о тех из них, чьи личности ранее изучены не были. Это руководители 1-го Московского пулемётного, Рязанского пулемётного и Телавского пехотного училищ.

Таким образом можно утверждать, что в результате проведенного исследования в научный оборот введены сведения, которые ранее нигде не представлялись. Наиболее интересные с нашей точки зрения моменты изложены в данной статье.

\section{Рязанское пехотное учимише}

В должности начальника училища с 1 января 1941 года по 11 июля 1946 года находился генерал-майор Гарусский Михаил Петрович. Следовательно, на протяжении всей Великой Отечественной войны в учебном заведении был один руководитель, что положительно сказывалось на формировании офицерского коллектива и как следствие на качестве подготовки курсантов. Генерал-майор Гарусский, 1894 года рождения, участник Первой мировой войны. Один из немногих награждён тремя орденами Красного Знамени РСФСР в годы Граж- данской войны (1919, 1921, 1922). За руководство училищем награждён орденом Ленина. За выслугу лет в РККА также награждён орденами Ленина и дважды Красного Знамени [1]. Автор нескольких научных статей по методике обучения курсантов. Выполнял обязанности начальника Рязанского гарнизона. Уволен с военной службы 11 июля 1946 года.

\section{Рязанское артимлерийское училише}

Полковник Верёвкин Александр Михайлович стоял у истоков создания Рязанской артиллерийской школы, которая во время его руководства 16 марта 1937 года была преобразована в училище. Верёвкин А.М. родился 21 августа 1896 года в Вильно (ныне Вильнюс). Информация о трудовой деятельности, обучении и участии его в боевых действиях в личном деле отсутствует. Однако в учётнопослужной карте офицера имеются сведения, что он был ранен в 1914 году. В Царской армии имел воинские звания: прапорщик, подпоручик, поручик, штабс-капитан. Во время Февральской и Октябрьской революций находился на Западном фронте. В сентябре 1918 года добровольно вступил в РККА. Участник Советско-полькой войны 1919-1921 гг. Далее, до назначения на должность начальника Рязанской артиллерийской школы служил на различных должностях в артиллерийских воинских частях и неоднократно обучался на курсах усовершенствования командного состава. Арестован 27 декабря 1937 года и до февраля 1940 года находился вместе с несколькими своими подчинёнными офицерами под следствием. Все они подвергались пыткам, но никто из них не оговорил ни себя, ни сослуживцев. После расстрела Народного комиссара внутренних дел Ежова они оказались на свободе. В связи с оправданием время нахождения под арестом было засчитано в срок службы на должности начальника училища. Назначен преподавателем кафедры артиллерии Военной академии Красной армии им. М.В. Фрунзе. С 5 сентября по 4 ноября 1941 года воевал в должности начальника штаба артиллерии Западного фронта. Далее, после лечения от заболевания, с 13 августа 1942 года служил старшим преподавателем артиллерии в вышеназванной академии. Умер 3 января 1946 года. За боевые отличия награждён не был. За выслугу лет в РККА награждён орденами Ленина и Красного Знамени [2, с.92-94].

Далее, до 26 марта, а фактически до мая 1941 года училищем руководил полковник, с 4 июля генерал-майор артиллерии Журавлёв Даниил Арсентьевич. В последствии видный военный деятель генерал-полковник артиллерии, начальник радиотехнических войск и службы ВНОС ПВО СССР [2, с.94-96].

Временно, с 11 мая по 1 июля 1941 года, полковник Мелуп Ян Янович исполнял должность начальника училища. Опытный офицер-артиллерист. На военной служ- 
бе с января 1918 года. Проходил службу на различных артиллерийских должностях. С 1938 года служил в училище помощником по тактике командира дивизиона курсантов. С 26 апреля по 4 октября 1941 года начальник учебного отдела - помощник начальника училища по учебно-строевой части. Участник Великой Отечественной войны. Награждён пятью орденами. Проживал в Риге. Умер 6 марта 1960 года [2, с.96, 97].

С октября по ноябрь 1941 года училище эвакуировалось в станицу Талгар Алма-Атинской области Казахской ССР и находилось там до февраля 1945 года. В данный период времени училищем руководили опытные офицеры-фронтовики: полковник Усов Алексей Варфоломеевич и генерал-майор артиллерии Головановский Ричард Иванович.

Возглавил училище 25 сентября 1944 года и руководил его передислокацией в Рязань в 1945 году генералмайор артиллерии Волчек Аркадий Николаевич. Опытный офицер-артиллерист, командовавший на северном фасе Курской дуги 21-ой отдельной миномётной бригадой РГК четырёхполкового состава. Впервые применил массированный миномётный удар на узком фронте 2-4 км по большому количеству атакующих немецких танков (от 100 до 300 танков). Во время этих боёв был ранен, награждён орденом Суворова 2-ой степени и произведён в генерал-майоры артиллерии. Соединение было преобразовано в 35-ю гвардейскую миномётную бригаду РГК. В должности начальника училища находился до 18 апреля 1950 года [3].

\section{Военно-политическое училише Запанного фронта (Белорусского особого военного округа)}

Начальником училища 14 ноября 1938 года назначен заместитель начальника политотдела Смоленского артиллерийского училища батальонный комиссар Матюкин Герасим Васильевич [4, л.1].

Родился 4 марта 1905 года. Окончил Ульяновское пехотное училище в 1930 году, в 1937 году Военно-политическую академию. После расформирования училища продолжил службу с 1 августа 1943 года военным комиссаром Ленинского военного комиссариата города Москвы. Уволен в отставку с должности военного комиссара Новосибирской области в 1952 году [5].

\section{1-е Московское пулемётное училише}

В должности начальника училища за время его функционирования проходили службу два офицера: подполковник Петрикей А.И. и полковник Юркин М.Г.

Подполковник Петрикей Афанасий Иванович 1895 года рождения. Родился в селе Мутин Кролевецкого уез- да Черниговской губернии. Участник Гражданской войны в 1919 году против банд Зеленого, Деникина, Юденича. В начале Великой Отечественной войны исполнял должность начальника учебного отдела Винницких курсов младших политруков. С 29 мая 1942 года начальник Московского пулемётного училища. Снят с должности 1 февраля 1943 года и назначен с понижением заместителем начальника Львовского пехотного училища [6]. Согласно карточке безвозвратных потерь, хранящейся в ЦАМО в картотеке учёта офицерского состава, покончил жизнь самоубийством 17 февраля 1943 года [7].

Полковник Юркин Михаил Григорьевич родился в 1900 году в деревне Тарбеево, которая позже вошла в Кировский район Кировской области. Окончил 1-е Советские Казанские командные курсы красных командиров в 1920 году. Участник боевой операции в июле-августе 1931 года по ликвидации бандитизма под городом Нарымом. Великую Отечественную войну встретил в должности заместителя коменданта управления коменданта Московского кремля. С 3 февраля 1943 года по 30 марта 1944 года начальник 1-го Московского пулемётного училища. После преобразования его в апреле 1944 года в Объединённое польское военное училище назначен его начальником. Звание «генерал-майор» присвоено 11 июля 1945 года. Службу закончил заместителем начальника главного военно-строительного управления военного министерства СССР 11 апреля 1955 года, а 2 июня 1955 года уволен в запас [8]. Награждён орденами Ленина, Красного Знамени - дважды, Отечественной войны 1-й ст., медалью «За отвагу», многими иностранными наградами [9].

\section{Рязанское пулемётное училише}

Формировал училище полковник Свищев Михаил Романович, родился 13 ноября 1895 года в станице Успенской (позже вошла в состав Ильинского района Краснодарского края). Там же в 1909 году окончил двухклассное министерское училище. С мая 1908 года по октябрь 1913 года работал по найму в крестьянстве, пас общественных лошадей. До марта 1916 года приказчик частного магазина станицы Успенской. Окончил экстерном 4 класса гимназии в Кропоткине (бывший хутор Романовский). В мае 1916 года мобилизован в Царскую армию и направлен рядовым учебной команды при 220м запасном полке, в нём же продолжил службу младшим унтер-офицером. Полк дислоцировался в Махачкале. С марта по май 1917 года являлся вольноопределяющимся батальона, дислоцированного в урочище Лагодехи. С июня по ноябрь 1917 года обучался в Тифлисской школе прапорщиков в должности юнкера. С декабря 1917 года по январь 1918 года служил младшим офицером 187-го пехотного полка Старой армии в городе Нахичевани. Продолжил службу в 1-м Кавказском народном полку Ростовского фронта: с апреля 1918 года рядовым, 
с сентября 1918 года командиром батальона, с октября 1918 года помощником командира полка. С февраля по март 1919 года в должности помощника командира 23го стрелкового полка 4-й стрелковой дивизии Южного фронта. Далее, до августа 1919 года в должности помощника адъютанта 330-го стрелкового полка 37-й стрелковой дивизии Южного фронта. В том же полку назначен командиром батальона. С сентября по ноябрь 1919 года в той же дивизии помощник начальника штаба по оперативной части. Член ВКП(б) с ноября 1919 года. До апреля 1920 года помощник командира 330-го стрелкового полка. До июля 1920 года командовал батальоном 248-го стрелкового полка 28-й стрелковой дивизии. В составе той же дивизии с июля 1920 года по июль 1922 года прошёл 7 переназначений в 248-м и 249-м стрелковых полках. За данное время 9 месяцев в должностях заместителя командира полка и 15 месяцев командира полка.

Участник Гражданской войны в 1918 году на Южном фронте против Деникина и в 1920-1921 годах против дашнаков и мусаватистов в Закавказье: в Азербайджане и Армении, в районах Баку, Нагорном Карабахе, Шуше, Зангезуре, Ленкоранском уезде - на границе с Персией. За данные действия награждён часами, револьвером, дважды представлялся к ордену, но награждён не был.

В 28-й стрелковой дивизии до октября 1923 года служил помощником командира 83-го стрелкового полка в городе грозном. По ноябрь 1923 года на такой же должности в 37-м стрелковом полку 13-й стрелковой дивизии в районе Темир-Хан - Шура. Далее, до октября 1924 года в Мариуполе помощник командира 238-го стрелкового полка. Обучался на курсах «Выстрел» в Москве, по окончании которых в августе 1925 года назначен помощником начальника 1-й части 7-го стрелкового корпуса в Днепропетровск. С октября 1925 года помощник командира 138-го стрелкового полка по хозяйственной части. Полк входил в состав 46-й стрелковой дивизии и дислоцировался в Переяславле Киевском. В октябре 1930 года принял командование 20-м стрелковым полком 7-й стрелковой дивизии в Чернигове. С июля 1931 года по июнь 1932 года командовал 195-м стрелковым полком 65-й стрелковой дивизии в Ишиме Омской области. Далее до августа 1937 года командовал 193-м стрелковым полком той же дивизии. Полк дислоцировался в Тюмени. Арестован по клеветническим материалам 22 августа 1937 года особым отделом 65-й стрелковой дивизии. Окружной партийной комиссией Уральского военного округа исключён из партии за связь с врагами народа и находился под арестом до июня 1939 года. Обвинялся по 58-й статье уголовного кодекса. Восстановлен в партии 1 мая 1939 года той же комиссией, а решением прокурора УВО 22 мая освобождён без суда, восстановлен во всех правах. Из сообщения коменданта города Свердловска начальнику 1-го отдела управления по комначсоставу РККА от 1 июня 1939 года №10/2106: «Товарищ Свищев был под влиянием комбрига Гаврюшенко, ныне врага народа. Влияние развращённо влияло на психику товарища Свищева, и я лично делаю такой вывод, что если бы товарищ Свищев не был под влиянием Гаврюшенко, то у него таких резко выраженных отрицательных сторон было бы меньше». С июня по 31 августа 1939 года состоял в распоряжении управления по командно-начальствующему составу РККА. До февраля 1940 года старший преподаватель тактики Чкаловских курсов усовершенствования начсостава запаса. До января 1941 года исполнял должность начальника Рузаевских курсов усовершенствования начсостава запаса. Назначен начальником отдела боевой подготовки 16-й армии Забайкальского фронта, которая с июля 1941 года вошла в состав Западного фронта. Ранен 17 июля 1941 года и до февраля 1942 года находился на лечении в 1-м коммунистическом госпитале в Москве. До февраля 1942 года служил начальником Подольского военного училища. Далее, полковник Свищев, начальник Рязанского пулемётного училища. Фрагмент из характеристики полковника Свищева, данной 19 октября 1942 года помощником командующего войсками МВО по ВУз генерал-майором Цыгановым: «Училище, которым он командует в настоящее время, сформировано недавно. Формируя училище, полковник Свищев показал себя неплохим организатором. Боевая и политическая подготовка курсантов организована удовлетворительно. Командирская учёба организована и проводится в разрезе требований подготовки современных кадров. Чётко начеливает личный состав и партийно-комсомольскую организацию на выполнение задач боевой подготовки и требований приказа Наркома Обороны №227. Воинская дисциплина как среди курсантов, так и среди комначсостава училища удовлетворительная. Достаточно требователен к подчинённым, обладает твёрдым характером». Однако, как видно из документов личного дела, ситуация в училище менялась в худшую сторону. Выписка из отношения заместителя командующего войсками Московского военного округа по вузам генерал-майора Цыганова № HP 02179 от 13 августа 1943 года: «... 7. В начале июня месяца училище проверял лично командующий войсками, нашёл его в неудовлетворительном состоянии и дал месячный срок на исправление, итоги этой проверки я передал Вам лично. 8. 4-5 июля с.2. по указанию командующего войсками я лично проверил состояние училища, оно оказалось в более худшем, чем при проверке командуюшим в начале июня месяца...».

В июле 1943 года в распоряжении главного управления кадров НКО СССР. До августа 1943 года преподаватель кафедры общей тактики Военной ордена Ленина Краснознамённой академии им. Фрунзе. До 10 сентября 1946 года преподаватель тактики курсов «Выстрел» в Смоленске. Назначен начальником военной кафедры Запорожского педагогического и учительского института. Уволен в запас 7 мая 1947 по состоянию здоровья. Рабо- 
тал на заводе «Красный молот» в городе Грозном.

Неоднократно избирался членом различных выборных органов:

в 1919 году член президиума ячейки ВКП(б) 330-го сп 37-й сд;

в 1922 году член президиума ячейки ВКП(б) 83-го сп в Грозном;

с 1923 года по 1924 год член президиума ячейки ВКП(б) 238-го сп в Мариуполе;

С 1926 года по 1927 год член президиума ячейки ВКП(б) 138-го сп в Переяславле Киевском;

с 1931 года по 1932 год член Ишимского городского совета;

с 1936 года по 1937 год член Тюменского городского совета;

Семья: жена Свищева (Канаткина) Олимпиада Григорьевна 1902 г.р., дочь Елена 1926 г.р., сын Игорь 1935 г.р.

Ранен 17 июля 1941 года в левую ногу с переломом костей в боях под Смоленском.

Награждён орденами Ленина (за выслугу лет в РККА), Красного Знамени - дважды (второй орден за выслугу лет в РККА), многими медалями [10, л.1-54 с об].

Генерал-майор Кирзимов Александр Ильич, родился 12 декабря 1897 года в городе Верном (в настоящее время Алма-Ата) Семиреченской области Казахстана. При рождении Саламсаков Такир-Али Еризбаевич. Татарин. Изменил фамилию, имя и отчество в детстве при принятии православной веры. В 1910 году окончил 2-х классное городское училище города Верного. С 1910 по 1913 год работал мальчиком (подростком рабочим) у местных кулаков в Верном, уволился из-за небольшой заработной платы. Далее, до 1915 года рабочий табачной плантации. Мобилизован в Царскую армию 13 августа 1915 года солдатом 120-го запасного батальона. Окончил учебную команду в 1916 году. По 24 февраля 1917 года рядовой на Западном фронте, до октября 1917 года взводный унтер-офицер 18-го пехотного полка Туркестанского фронта. Демобилизован при распаде временного правительства. До Октябрьской революции участник революционного движения. В 1917 году в Ташкенте принимал участие в разоружении школы прапорщиков и кадетского корпуса. Там же, 24 января 1918 года, вступил в Красную гвардию в должности командира особого взвода 1-го советского полка. В Красную Армию вступил добровольно 27 февраля 1918 года, назначен начальником конной разведки 1-го рабоче-крестьянского социалистического полка, который дислоцировался в Ташкенте. Обучался на политкурсах военкомов при политотделе 3-й стрелковой дивизии Туркестанского фронта с февраля по май 1919 года. Член ВКП(б) с 12 марта 1919 года. Фрагмент из автобиографии: «Отеи умер в 1911 году, мать умерла во время голода в 1920 году». С 15 августа 1918 года по 4 февраля 1920 года служил в городе Верном помощником командира эскадрона 5-го кавалерийского полка, до 9 июля 1920 года там же военком эскадрона. Далее, до 19 января 1921 года на такой же должности в 4-м кавалерийском полку РККА на Туркестанском фронте. Командир эскадрона данного полка до 5 декабря 1921 года. Из аттестации Кирзимова за 19191921 годы, данной командиром 46-го горского дивизиона: «Участвовал на Семиреченском фронте и в экспедиции по горной Восточной Бухаре. Все обязанности исполнял честно и аккуратно. Своим примером и храбростью подавал пример и воодушевлял красноармейцев». Продолжил службу до 23 марта 1922 года в Термезе командиром 34-го эскадрона 36-й пограничной бригады ВЧК. В Бухаре до 25 февраля 1923 года политначальник сводного отряда ВЧК. До 1 мая 1924 года командир 5-го отдельного пограничного эскадрона ВОГПУ в Джаркенте, в данный период службы являлся начальником района охраны Китайской границы. Помощник коменданта 7-го погранотряда ВОГПУ до 9 февраля 1925 года в Керки. Там же, на такой же должности до 1 ноября 1925 года в составе 47-го Узбекского погранотряда ВОГПУ. Переведён в Грозный и до 15 января 1926 года служил помощником командира дивизиона 53-го Чеченского дивизиона ОГПУ. На равнозначной должности до 22 апреля 1927 года во Владикавказе в 46-м горском дивизионе ВОГПУ. Продолжил службу командиром дивизиона Грозненского отряда ОСНАЗ ОГПУ. С 9 ноября 1929 года по 8 июля 1930 года обучался на Новочеркасских курсах усовершенствования комначсостава РККА, по окончании которых назначен помощником командира отдельного СевероКавказского национального кавалерийского дивизиона ВОГПУ в городе Нальчике. С 27 октября 1931 года по 1 октября 1932 года исполнял должность командира 48-го Дагестанского дивизиона ВОГПУ в Махачкале. Далее, до 10 июня 1934 года в Пятигорске исполнял должность командира - военкома 81-го Пятигорского кавалерийского полка ВОГПу.

С 1918 года по 1933 год неоднократно участвовал в боевых действиях на фронтах Гражданской войны, против врагов социалистического отечества, ликвидации бандитизма, при столкновениях по охране государственной границы, находился в оперативных командировках. За данные действия многократно награждался и поощрялся командованием. Командиром 34-го эскадрона 36-й отдельной бригады за умелое руководство боем под Кабадианом на реке Кафарнингане награждён 5 января 1922 года пистолетом «Маузер» №75106. Командиром этого же эскадрона за бой под Какойтаном награждён 20 февраля 1922 года саблей. Политначальником сводного экспедиционного отряда ВЧК за умелое руководство в бою под Кузбулатом в Келифском районе и уничтожении бандшайки во главе с руководителем Тунеген-беком 30 апреля 1922 года объявлена благодар- 
ность. Тем же начальником 23 июня 1922 года награждён орденом Бухарской Красной Звезды за активное участие в борьбе с басмачеством на территории восточной Бухары. Помощником коменданта 47-го Узбекского погранотряда за образцовое оборудование казарм 25 апреля 1925 года объявлена благодарность. Командиром дивизиона Грозненского отряда ОСНАЗ ОГПУ за безупречную службу в отряде в 10-ю годовщину ВЧК-ОГПУ 24 декабря 1927 года объявлена благодарность. За долголетнюю и безупречную службу в РККА в день 10-й годовщины, тем же начальником 13 марта 1928 года награждён часами. Помощником командира Северо-Кавказского национального кавалерийского дивизиона за беспощадную борьбу с контрреволюцией и бандитскими шайками был награждён 20 декабря 1930 года часами и грамотой. Им же был награждён Кирзимов 23 февраля 1931 года пистолетом «Браунинг» и грамотой за 13-ти летнюю службу в РККА. За проявленное мужество и энергию в борьбе с контрреволюционным элементом, исполняющим должность командира 48-го Дагестанского дивизиона ВОГПУ 23 февраля 1932 года награждён боевым оружием - серебряной шашкой и грамотой. Исполняющим должность командира 81-го Пятигорского кавалерийского полка ВОГПУ за большевистское руководство динамовской работой 11 декабря 1932 года был награждён пистолетом Коровина. В дальнейшем этим же начальником был награждён еще два раза: 11 марта 1933 года за самоотверженную работу по руководству ликвидацией бандитизма в Чечне строевой лошадью; 1 июля 1933 года за самоотверженную работу по руководству операцией Терским оперсектором также был награждён строевой лошадью. Состоял в резерве до 23 ноября 1934 года при ГУПВО НКВД. До 9 сентября 1936 года обучался в Военной академии РККА им. Фрунзе. Партийный билет №1013707, выдан политотделом академии. Во время обучения Постановлением ЦИК СССР 14 февраля 1936 года в день 15-летия погранохраны награждён орденом Красного Знамени. По окончании учёбы назначен в Броды командиром 16-го кавалерийского полка НКВД. Награждён медалью «XX лет РККА» Указом ПВС СССР от 22 февраля 1938 года. Приказом НКВД №305 от 1938 года за беспощадную борьбу с контрреволюцией награждён знаком Почётного работника ВЧК-ОГПУ-НКВД. Фрагмент из автобиографии: «С полком 17 сентября 1939 года прибыл в Западную Украину для принятия участия в освобождении народности Западной Украины от польской помещичьей кабалы». Командиром данного полка встретил Великую Отечественную войну, на второй день которой в бою в районе города Броды 24 июня 1941 года был ранен осколком гранаты в ногу и бедро (согласно первоисточнику). С июля по 24 августа 1941 года командовал 265-й стрелковой дивизией Ленинградского фронта. Отстранён от должности, находился в распоряжении Военного совета Ленинградского фронта до 14 сентября 1941 года. Звание «генерал-майор» присвоено 15 июля 1941 года. В должности командира 6-й отдельной стрел- ковой бригады Ленинградского фронта до 28 декабря 1941 года. До 4 января 1942 года в распоряжении ГУК НКО. Назначен командиром 105-й кавалерийской дивизии Среде-Азиатский военного округа. Со 2 августа по декабрь 1942 года исполнял должность командира 6-го воздушно-десантного корпуса. Далее, до 20 марта 1943 года командовал 6-й гвардейской воздушно-десантной дивизией, которая в феврале 1943 года вошла в состав Северо-Западного фронта. Далее, до 9 июля 1943 года командовал 380-й стрелковой дивизией Северо-Западного фронта. Находился в распоряжении ГУК НКО до 26 июля 1943 года. В должности начальника Рязанского пулемётного училища до 31 августа 1945 года, после расформирования которого находился в распоряжении ГУК НКО до 8 мая 1946 года. Уволен из рядов Красной Армии по болезни. Проживал в Москве. Умер 7 ноября 1955 года (согласно личному делу, 7 мая 1955 согласно УПК). Похоронен на Введенском кладбище Москвы.

Неоднократно избирался членом, делегатом и депутатом различных выборных органов:

в 1921 году член первого созыва комиссии по чистке рядов Коммунистической партии Туркменистана в городе Термезе;

с 1927 года по 1928 год член районной комиссии районной партийной конференции Чечено-Ингушской АССР в Грозном;

с 1933 года по 1934 года член бюро городского комитета ВКП(б) в Пятигорске;

с 1936 года по 1939 год член пленума областного комитета ВКП(б) в Махачкале, там же в этот период времени являлся членом бюро городского комитета ВКП(б) и членом городского совета депутатов;

в 1938 году делегат 18-го съезда ВКП(б) в Махачкале;

с 1936 года по 1938 год делегат областной парткомиссии в Махачкале;

в 1938 году депутат первого созыва Верховного совета РСФСР по 647-му избирательному округу Дагестанской АССР в Дербенте.

Как отмечено в личном деле, свободно говорил на узбекском, тюркском языках, слабее на таджикском, китайском, кумыкском и английском языках.

Состав семьи: жена Кирзимова (Шашкова) Елизавета Филипповна 1899 г.р., дочь Людмила 1920 г.р., дочь Аделаида, 1925 г.р., сын Владимир 1939 г.р.

Имел 4 ранения: в 1916 году, находился на лечении в Сызрани, дважды ранен в Гражданскую войну на Туркестанском фронте, 24 июня 1941 года в районе Броды.

Награждён орденами Ленина (за выслугу в РККА), Красного Знамени - дважды (второй орден за выслугу в РККА), Отечественной войны 1-ой степени, Красной Звезды Бухарской Республики, многими медалями [11, л.1-48 с об.]. 


\section{Телавское военное пехотное учияише}

Передислокацией училища из Телави в Скопин непосредственно руководил начальник училища полковник Клименко Лонгин Алексеевич, назначенный на эту должность 28 октября 1942 года, в которой служил до 11 января 1943 года. Назначен начальником Краснодарского пехотного училища, скоропостижно скончался от болезни 14 февраля 1943 года. Далее, с 10 февраля по 28 июня 1943 года, Телавским пехотным училищем руководил полковник Комаров Фёдор Иванович. Кадровый военный, родился 1 января 1901 года в Воскомирском уезде Ковенской губернии Литвы. Окончил в 1925 году Нижегородскую пехотную школу, в 1927 году Ленинградские военно-политические курсы им. Энгельса и в 1937 году Военную академию РККА им. Фрунзе. До ранения, полученного 9 сентября 1942 года, воевал в должности заместителя начальника штаба 1-ой гвардейской армии Сталинградского фронта. С октября по декабрь 1943 года исполнял должность начальника штаба 52-го стрелкового корпуса. Получил ранение. После завершения лечения в январе 1944 года находился в распоряжении ГУК НКО и Военного совета 1-го Украинского фронта до февраля 1945 года. Назначен начальником штаба 11-го стрелкового корпуса. С августа 1945 года по август 1946 года начальник штаба 242-й горно-стрелковой дивизии. Уволен в запас 30 августа 1946 года с должности начальника штаба 3-го горно-стрелкового корпуса. Награждён орденами Ленина, Красного Знамени - трижды, Кутузова 2-ой степени и Отечественной войны 1-й степени [12].

На завершающем этапе функционирования училища в должности начальника служил полковник Соловьев Павел Николаевич (с 28 июня 1943 года по 1 октября 1946 года). За руководство училищем 22 февраля 1944 года награждён орденом Красной Звезды [13, л.8]. Вместе с ним данным приказом были награждены ряд офицеров вверенного ему училища, а также офицеры 1-го Московского пулемётного училища.

\section{ОрАжоники зеграсккое автомобильно-моточиклетное училише}

С 16 октября 1942 года по август 1946 года училищем руководил полковник (далее генерал-майор) Лашко Иван Романович, родился в 1900 году в городе Темрюке Краснодарского района Ростовской области. С ноября 1917 года на военной службе добровольно, вступил в Замостьянский батальон города Темрюка. С 1918 года по 1920 год работал кочегаром в пароходстве, находился на территории, занятой белой армией. Чтобы избежать мобилизации, трудовую деятельность вёл по документам младшего брата. Далее обучался на кавалерийских курсах РККА, участвовал в подавлении выступления бандформирований Антонова. Далее служил офицером-кавалеристом на различных должностях в ряде кавалерийских воинских частей. В 1934 году окончил Военную академию Красной армии им. М.В. Фрунзе. Продолжил службу в механизированных воинских частях. Участвовал в походе по освобождению Западной Украины и в Советско-финляндской войне. В начале Великой Отечественной войны в должности начальника штаба 7-й моторизованной дивизии 8-го механизированного корпуса в составе Юго-Западного фронта. С конца июня 1941 года в той же дивизии заместитель командира. С сентября 1941 года командир 2-й танковой бригады на Южном фронте. После полученного ранения и лечения, в октябре 1942 года назначен начальником Орджоникидзеградского автомобильно-мотоциклетного училища. Руководил в июне 1943 года передислокацией ранее эвакуированного в Минусинск Красноярского края училища в Рязань. На новом месте дислокации в кротчайшие сроки были проведены мероприятия по созданию необходимых условий для учёбы. Оборудованы казармы, созданы учебные классы, лаборатории, мастерские, стрельбище, автопарк и автодром. С августа 1946 года по 1948 год полковник Лашко командовал отдельным учебным автомобильным полком. Далее, до 1961 года возглавлял Военно-техническое училище им. Б. Хмельницкого. Награждён орденом Ленина и пятью орденами Красного Знамени [14, с.23, 30, 31].

\section{1-я Рязанская высшая школа штурманов BBC KAAA}

Начальником школы с 12.1940 г. по 1.10.1945 г. служил Герой Советского Союза генерал - майор Беляков Александр Васильевич. Участник многих рекордных авиационных перелётов в 1930-е годы в одном экипаже с В.П. Чкаловым [15].

\section{Школа санинструкторов №3 MBО}

Начальниками школы были: с января по 18 сентября 1941 г. военврач 1 ранга Гусев Владимир Николаевич; с 18.09.41 г. по 31.12.45 г. военврач 2 ранга, далее майор м/с Введенский Пётр Александрович [16].

\section{3-я Военная авиашионная школа пилотов первоначального обучения}

Начальник школы с 14.12.1943 г. по 5.02.1946 г. подполковник Белецкий Антон Федосеевич [17].

\section{Школа танковых спешиалистов при 1-м Польском армейском корпусе}

Находилась в Рязани и функционировала с 1943 года по 1944 год. Начальником школы на 1944 год служил майор, далее подполковник Король Дмитрий Васильевич [18]. 


\section{ЛИТЕРАТУРА}

1. ЦАМО. Картотека учета награждённых, УКН генерал-майора Гарусского.

2. Ларин Г.В. Рязанское артиллерийское училище. История в судьбах командиров и выпускников. - Рязань: ГуП РО «Рязанская областная типография», 2019. - 304 с.: ил. - Серия «Помнить обязаны». С. 92-97.

3. ВКРО. Личное дело генерал-майора артиллерии Волчека.

4. РГВА. Ф. 34912. Оп. 1. Д. 4723. Л. 1.) Исторический формуляр Военно-политического училища Белорусского Особого военного округа (Западного особого военного округа.

5. ЦАМО. Картотека учета офицерского состава, УПК полковника Матюкина Г.В.

6. ЦАМО. Картотека учета офицерского состава, УПК подполковника Петрикея.

7. ЦАМО, Картотека учёта офицерского состава, КБП Петрикея А.И.

8. Ц ЦАМО Картотека учета офицерского состава, УПК генерал-майора Юркина.

9. ЦАМО Картотека учета награждённых, УКН генерал-майора Юркина.

10. ЦАМО. Личное дело полковника Свищева М.Р. Л. 1-54 с об.

11. ЦАМО. Личное дело генерал-майора Кирзимова А.И. Л. 1-48 с 06.

12. ЦАМО. Картотека учета офицерского состава, УПК полковника Комарова Ф.И.

13. ЦАМО. Ф. 33. Оп. 686043. Д. 13.Л. 8.

14. Военно-исторический очерк. 70 лет. Люди. События. Факты. Под общей редакцией начальника Рязанского военного автомобильного института доктора педагогических наук, профессора А.Н. Герасимова, стр. 23, 30, 31.

15. ЦАМО. Ф. 60676. (1-я Рязанская высшая офицерская школа ночных экипажей АДД ВВС КА) Краткая историческая справка войсковой части.

16. ЦАМО. Ф. 61505. (Школа санинструкторов №3 МВ0) Краткая историческая справка войсковой части.

17. ЦАМО. Ф. 60410. (3-я Военная авиационная школа) Краткая историческая справка войсковой части.

18. ЦАМО. Ф. 61074. (Школа танковых специалистов при 1-м Польском армейском корпусе) Краткая историческая справка войсковой части.

() Ларин Геннадий Владимирович (larin191975@yandex.ru).

Журнал «Современная наука: актуальные проблемы теории и практики»

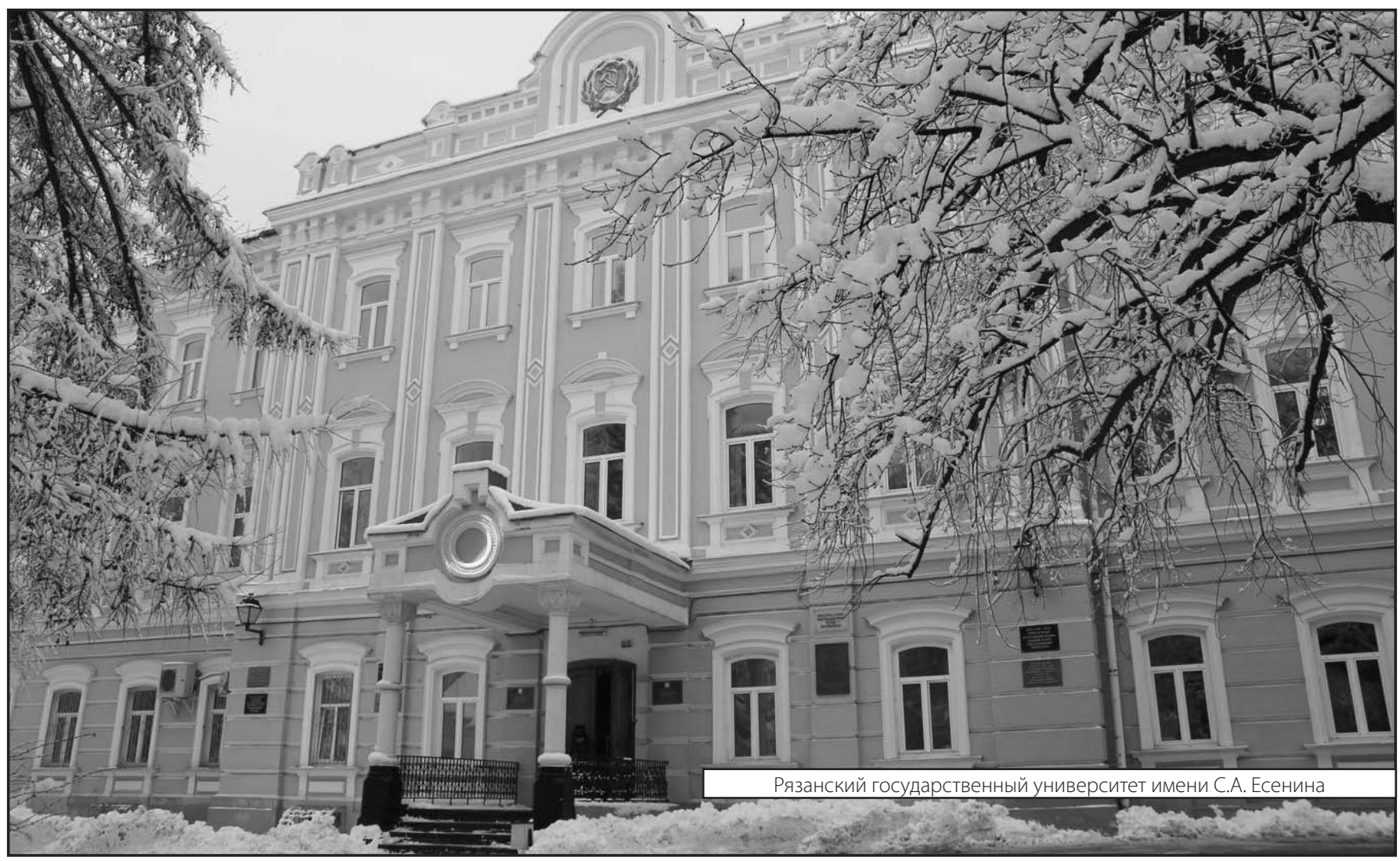

